\title{
Social Work Education in Europe: A Retrospective View
}

\section{Karen Hamilton Lyons}

The introduction of European funding in the 1980s played an important part in the establishment of networks contributing to the learning opportunities of social work students in the latter part of the twentieth century and more recently. While the number of British social work schools participating were in the minority, membership of networks contributed to the growth in knowledge about European frameworks and comparative social work and professional education. This has subsequently became formalised through edited (comparative) texts and research projects. Use of the term 'social professionals' highlights both the central importance of 'the social' and the diversity of educational and professional awards and occupational groups engaged in this broad field. The experience in networks introduced staff and students alike to different ways of thinking about the roles of the state and the family and of organising work in relation to a range of often similar social problems. British participation was sometimes hindered by language limitations, but European experience introduced new vocabulary such as subsidiarity, social pedagogy and social exclusion. It has also served to illustrate the narrowing of British social work; the high degree of regulation and the dichotomy between education and training evident in the UK.

Keywords European networks; European context; European funding; social pedagogy; social professionals

\section{Introduction}

This is a significant point in the history of social work - and in the relationship between the UK and Europe - to reflect on social work education and training in the European context. The UK and other European countries played an important role in the nineteenth century origins of social work and (in the early years of the twentieth century) education for its practice on both sides of the North Atlantic (Kendall 2000). Given its concerns with 'the urban poor', it is not surprising that many philanthropic and reforming initiatives - which subsequently became known as social work - developed in cities across Europe and the USA. In the UK, these origins are most frequently attributed to the work of the Charity Organisation Society (COS), but there was also an important social action strand, represented in the work of settlements and of individual pioneers, who championed the need for welfare developments (including public health measures and decent housing) and provisions for particular groups, such as neglected children. There was also an often omitted element in this history, that is, the 'statutory' strand, as represented in the Poor Law provisions and work in relation to young offenders and courts (Walton 1975AQ2).

By the early twentieth century, there was a recognition of the need for 'education' of 'social workers' in Britain (beyond the training of volunteers already provided through COS) and courses were established at universities such as London (LSE 1903/1912) and Birmingham (1908). However, it seems that the first social work course was established in the Netherlands (Amsterdam, 1899), with others following in Europe, for example, in Germany (Berlin, 1908) and France (Paris, 1913). The first half of the twentieth century saw an expansion of education courses into many northern and central European countries as well as in the USA and elsewhere with subsequent phases of development post-Second World War and from the 1990s.

It is worth noting the important role played by women, such as Alice Salomon (Germany) and Helena Radlinska (Poland), in these early developments and also in the organisation of the first 'International Conference of Social Work' held in Paris (1928; Hering and Walldjik 2003).AQ1 This provided the impetus for the establishment of the modern day international bodies representing social work associations (International Federation of Social Workers - IFSW); schools of social work (International Association of Schools of Social Work - IASSW) and (predominantly) non-government organisations involved in welfare and humanitarian work (International Council on Social Welfare - ICSW). All these associations have European regional bodies involved in a range of activities aimed at information exchange and supporting conventions and policy initiatives relevant to their constituents and stakeholders.

However, this article is not primarily concerned with the origins of social work education, nor the history of its expansion in individual countries and spread worldwide over the course of the twentieth century (and into the twentyfirst in some states). Although systematic research and documentation of the international and European history of social work education is relatively sparse, there are (brief) accounts of such developments in the international social work literature (e.g. Lyons 1999ab; Healy 2001, 2012; Hokenstad 2012). 
The focus here is rather on developments in the latter decades of the twentieth century when a concern within the then European Economic Community (EEC) with a shift to greater political cohesion saw the beginnings of efforts aimed at 'harmonisation' in various policy areas. An important initiative in the higher education sector was the funding of student and staff exchange programmes called the ERASMUS scheme, the forerunner of schemes (including SOCRATES) that subsequently extended beyond the borders of what became the European Union (EU). Other funding programmes targeted other 'social' sectors, for example, through programmes aimed at addressing poverty (from the early 1990s, reframed as social exclusion) and also inequalities in society related to gender, race and disability. The growing body of literature about Social Work in Europe together with my experience since the 1980s in a large network (4AQ3) and through contributions to the establishment (or re-establishment) of social work education programmes in Russia and various Former Soviet Union (FSU) countries form the basis for this reflection on the contemporary history of social work education and Europe.

\section{Locating Social Work Education in Europe}

Before considering the varied nature of Social Work in Europe - and therefore the different patterns of education and training - it is important to think about what we mean by 'Europe' and Lorenz's (1994:1) view of Europe as 'not a fixed entity' but rather 'a project' is apposite. Geographically, Europe is a vast continent and, with a population of 743.1 million (2015), it is the third most populous continent in the world. In terms of contemporary history, Second World War (1939-1945) was a traumatic milestone prompting in 1949 the establishment of The Council of Europe. This was fashioned by the leaders of five previously warring countries (France, Belgium, Italy, UK and West Germany) to promote democracy and the rule of law in Europe. The Council, based in Strasbourg, now consists of 47 countries (ranging from Iceland and Russia in the north to Portugal, Turkey and Ukraine in the south) and proclaims itself as the leading human rights organisation in Europe (https://www.coe.int/web/aboutus).

This should not be confused with the EU, which has developed from an organisation also established in the post-war period by leaders of the same countries with the exception of the UK and the addition of Netherlands and Luxembourg. This was the European Coal and Steel Community (ECSC), dating from 1950 (Treaty ratification 1952) and aimed at removal of trade barriers in this particular sector. This in turn laid the basis for the Treaty of Rome which established the EEC in January 1958. This so-called 'Common Market' subsequently expanded -in terms of both membership and its remit, for example, Denmark, Ireland and the UK joined the six founder members in 1973. Renaming as the European Community (EC) marked a shift from purely economic policies, and from 1993, the Maastricht Treaty, ushered in free movement of goods, capital, services and people in the newly named EU (https://europa.eu/european-union/index).

The EU now consists of all the countries of mainland north, west and south Europe, with the notable exceptions of Norway and Switzerland. The ending of 'the Cold War' and changed political geography of Europe following the fall of the Berlin wall in 1989 eventually resulted in significant expansion with the addition of the Baltic States and central European countries previously dominated by the Soviet Union, such as Poland and Slovenia in 2004; Romania and Bulgaria in 2007; and Croatia in 2013, bringing membership to the 2018 total of 28 states. The EU functions on the basis of a number of institutions including an executive Commission; the Parliament, European Central Bank, Court of Justice (of EU) and various committees such as the Economic and Social Committee. It has to some extent acted as an instrument for the redistribution of money from richer to poorer member states and, as indicated earlier, has used competitive funding as a mechanism for promoting developments aimed at greater integration (Rodriguez-Pose 2002).

However, concerns have been raised about expense, democratic accountability, corruption and, most recently, the 'distribution' of asylum seekers and other migrants (still mainly clustered in countries bordering the Mediterranean, notably Greece). Arguably, these concerns were the basis for some of the 52\% of votes cast to leave the EU by a proportion of the British population in 2016. While this has resulted in considerable uncertainties nationally (notably about the relationship between Scotland and Northern Ireland and the other two constituent nations; and the UK and Ireland and, not least, all sectors of the economy), it has also exacerbated tensions between other member states and perhaps called into question the whole 'European project'.

In terms of this article, I suggest that the availability of ERASMUS and other funding streams shifted the debate about 'international social work' to a regional focus. It encouraged the building of networks and partnerships between schools of social work (or the social professions - see later) across a range of countries in Europe as well as across organisations representing some of the user groups and other professional bodies with which social workers are engaged. 
The changed relationships between East and West European countries had implications for social work since, in the 1990s, ERASMUS funding and network membership were extended to countries which would subsequently become the Accession States, as well as providing funding for projects in Russia and Ukraine. These relationships sometimes supported the rediscovery of the roots of social work and social pedagogy in countries where these occupations had been erased under a communist system which did not admit to social problems - or devised other ways of addressing them; and contributed to developments in services and professional education.

Another significant development occurred in 1999 when the proclamation of the Bologna Declaration initiated the process leading to the establishment of the European Higher Education Area in 2010 (Ginsburg and Lawrence 2006). However, despite the various processes aimed at 'harmonisation' and different projects based on shared working and joint awards, social work education for professional qualification remains firmly rooted in the educational traditions of particular countries and in the socio-economic, political and cultural national contexts within which social work is practised. A specific example of this can be seen in articles describing recent attempts to establish a European doctorate in Social Work (Leskosec and Matthies 2017) when efforts to include Ukraine were thwarted by national systems and policies (Semigina, Kabachenko, and Boyco 2017).

\section{Educating for Social Work - or Social Pedagogy - or the Social Professions?}

One of the striking things learned from engagement with social work schools in Europe was the variation in conceptions of social work and the resulting range of curricula and awards in professional education. For instance, the network of which I was a founding member (in 1986) ${ }^{1}$ was based on a series of bi-lateral partnerships dating from 1980 and led by a German school, where both social work (arbeit) and social pedagogy were taught. The network included educators from departments of social policy (Scotland), youth work (England) community work (Ireland), early years (Germany), human resource management (Netherlands) animation (Spain), social education/social pedagogy (Italy and Scotland) as well as social work (Greece, Sweden and the UK) and eventually extended to about 15 countries. It was not surprising therefore that the network leaders took a pragmatic approach to the question 'what constitutes social work?' and coined the term 'social professions' as a more inclusive description of the field. This term, identifying the core focus of the work of a range of occupational groups as 'social' (as opposed to health or education related), was subsequently formalised in the first editorial of the now well-established European Journal of Social Work (EJSW; Otto and Lorenz 1998) ${ }^{2}$.

In the 1980s and 1990s, there was little empirical research into social work or professional education in Europe $\mathrm{e}^{3}$ but the increase in the number of ERASMUS-funded networks and projects through these decades led to significant expansion of experiential learning and anecdotal evidence, sometimes formalised into presentations (for European seminars and conferences) and forming the basis for an increasing range of articles and publications into the twentyfirst century (e.g. Chytil and Seibel 1999; Laot 2001; Freitas et al. 2005; Littlechild Erath, and Keller 2005; Kantowicz 2009; Erath and Littlechild 2010). There was also little research into the extent to which British social work educators were engaging with Europe, although there was some encouragement to do so from the Central Council for Education and Training in Social Work (CCETSW; the body responsible for regulating British social work education between 1970 and 2001) as evidenced in their sponsorship of some conferences and publications (e.g. Cannan, Coleman, and Lyons 1990). By the mid1990s, 42 out of 64 UK leaders of social work courses who answered a questionnaire about involvement in 'international social work' said they had current or proposed partnerships with other European social work schools (Lyons, cited in Ford and Hayes 1996:147).

Of particular interest to British social workers has been the difference between social work (as understood in the UK) and social pedagogy - a relationship-based approach used in different settings and alongside different user groups in a range of European countries (Lyons and Huegler 2012; Hatton 2013).AQ1 Many of us who have worked with European partners view British social work as having developed into a very narrow field and, given criticisms of social work practices in both the child care field and residential work, earlier this century the Department of Health funded research by the Institute of Education into social pedagogy across various European countries to see whether 'lessons could be learned' (Boddy, Cameron, and Petrie 2006; Petrie et al. 2009). This has resulted in the establishment of a Social Pedagogy Association and a Centre for Understanding Social Pedagogy (CUSP) at the Institute, currently (2017) with funding for the development of an accredited training programme. Interestingly, and given its nineteenth century roots in Germany, this is taking place at a time when some German colleagues have been integrating the social work and 
pedagogy streams of education - and these qualifications have long been interchangeable in terms of successful students' employment options.

In terms of activities, ERASMUS funding offered a range of opportunities for staff and students including initial staff visits/meetings to establish short-term partnerships or longer-term networks. The main focus was on student exchange (for limited periods of study or practice placements) but funding sometimes enabled students to participate in jointly run courses (usually at masters' level) with a European or cross-national focus (Lyons and Lawrence 2006). A greater number of students were able to participate in intensive seminars when students from a small number of schools would meet together for up to 10 days to learn about selected 'social issues' and the attitudes and responses commonly adopted in their home and partner countries. Topics for these European-funded seminars included poverty, addictions and racism. Other funding streams, for example, PETRA Youth for Europe, resulted in similar projects some of which also formed the basis for publications (e.g. Aluffi-Pentini and Lorenz 1996). A number of networks have also held annual meetings with seminars specifically for staff and organised conferences (either individually or in collaboration with other European associations) and led or participated in research projects (e.g. Laot 2001). Over nearly four decades, these initiatives have resulted in the informal exchange of ideas and expertise; in formalised opportunities for knowledge transfer; and in knowledge creation, broadening the horizons of a wide range of social professionals.

\section{Social Work and the State}

There are wide variations across the EU in the extent to which the State is involved in social welfare, ranging from a high level in northern Europe to less or minimal levels in the Mediterranean countries and this has a bearing on the education and employment as well as roles, responsibilities and regulation of social professionals. At the time when networks were expanding and new ones were being established-, Esping-Anderson (1990) produced a useful typology of 'models of welfare' and these were subsequently drawn on as the basis for comparisons about social work.

In line with Esping-Anderson's 1990 typology, the Nordic countries are well known for the early and comprehensive development of 'welfare states' built on democratic and egalitarian principles, consensus politics and proportionate taxation. Social workers are most likely to be employed by the state (nearly $100 \%$ in the case of Denmark, where the professional association is also the trade union for this group) and, in the main, operate to a high professional standard in well-resourced facilities. (However, even countries such as Sweden have in the past decade been affected by economic crises and the shift to the right politically.) Social work education is routinely provided in the university sector (which is accessible to a relatively high proportion of young people) and the Nordic states co-operate to provide funding for research and evaluation studies.

The second model, Bismarkian, reflects the insurance-based principle which underpins the funding of welfare services in Germany but also France and some neighbouring countries. Also reflected in the organisation of welfare is the notion of 'subsidiarity' - another 'European term' previously unfamiliar to many English speakers but derived from Catholic social teaching, blending the principles of individuality (self-reliance) and solidarity (mutual bonds; Cannan et al. 1992).AQ1 In these countries, while the state provides financial support and often regulation, social services are largely provided by non-governmental organisations - and sometimes private enterprises. Some of these have their roots as religious charitable bodies, for example, St. Vincent de Paul, while others are 'branches' of large international organisations such as the Red Cross. In Germany, a high proportion of social professionals are employed in the 'Big Six' major welfare cartels, including CARITAS (Catholic origins); Jewish Welfare; and the secular 'Workers Welfare', while these may have originated to serve particular groups it is more likely that services are now provided on a geographical basis and not limited to the followers of a particular faith. - or nonAQ4. In Germany, while social pedagogy is traditionally taught in Education Faculties in the (old) university sector, social work is more generally taught in Fachhochschulen or 'Universities of Applied Science'. However, universities have quite high degrees of autonomy and the powers of the Lander (or provinces) can also lead to 'local variations' across a range of sectors.

Esping-Anderson (1990) labelled the third model as Liberal or 'Beveridgian' and described the UK welfare state as being based on a mixed model of insurance and taxation. It is also mixed in the sense of providing services which are a mix of universal and selective, with room for provisions by private and non-governmental agencies as well as the state - though it seems that the state has increasingly divested itself of responsibilities for a range of provisions and has increasingly 'encouraged' - or required - people to make their own arrangements individually or within 'the family', for example for pensions or elder care, than when Esping-Anderson first advanced this typology. 'The hollowing out' 
of the welfare state (Mishra 1999:52)AQ1 has been increasingly evident and, in this respect, the UK seems to have moved closer to the situation in other countries where greater reliance is placed on the informal sector (e.g. see 'Latin Rim' below). Continuing into the twenty-first century, changes have also been reflected in patterns of employment and, from working mainly in (large) social service departments (often over long periods of time), social workers now tend to have more fluid careers in a variety of organisations, including sometimes periods as 'agency workers' or 'selfemployed'. Despite the narrowing down of the (local) state's role in personal social services, it has played an increasing role in the inspection of services; the regulation of social work education; and the licensing of practitioners - to a greater degree than in other European countries.

Various critiques were raised in response to Esping-Anderson's typology, including the omission of a fourth variant where the state plays a relatively small part in the provision of various different forms of welfare. Abrahamson (1993) labelled this as 'the Latin Rim' and it includes Ireland, Italy, Portugal, Spain and Greece. Thus, it mainly describes countries where the Catholic Church has traditionally had a strong influence (or the Orthodox Church in the case of Greece) and where informal care has played a greater part than state provision across a range of sectors. These are countries based on rural economies, lacking substantial manufacturing histories, which have had relatively recent experience of civil conflict and economic problems during the twentieth century, providing few resources for welfare developments, even if there were the political will. Social work has developed relatively later than in the north European countries and professional education has only developed in the post-Second World War period. However, by the 1980s, there were a number of schools of social work keen to engage with European colleagues and - in line with its regional policies - ERASMUS networks that included participants from countries on 'the periphery' were favoured by the funders. However, But it is interesting to note that the Italian university sector continues to resist appointing Professors of Social Work; and in Greece, students gain their social work qualifications from Technical Education Institutes and are not eligible to proceed to higher degrees. Thus, with the exception of Ireland, the extent of 'academisation' of social work education is noticeably less in the Latin Rim countries than it is in Northern Europe. This characteristic was also evidenced in another network in which I participated - a Paris-based project researching doctoral developments in social work - when a clear finding was that the relatively few people from the Mediterranean countries who might identify as social professionals wishing to undertake doctoral studies were required to undertake their research under the umbrella of Education, Sociology or Psychology Departments. In contrast, in the Nordic countries there are well-developed 'doctoral programmes' explicitly linked to social work departments and supervised by social workers, with a more mixed picture across countries in between (Laot 2001).

A further development not anticipated in Esping-Anderson's work was the emergence of states in central and Eastern Europe which, increasingly since 1990, have been keen to participate in the capitalist system 'enjoyed' by their neighbours. Developments in various countries have included aspirations to develop social welfare provisions and, as in a previous phase, the EU was keen to encourage inclusion of countries such as the Czech Republic, Poland, Romania and the Baltic States in ERASMUS and other funding programmes. This was clearly to the advantage of these states and many projects operated to provide teaching and other resources to help get new educational programmes and services established. This was not entirely a one-way flow, in terms of both recovering the history of social work and social pedagogy in many of these countries; but also in enabling printing of material and the running of meetings and conferences in places that could provide facilities at less expense than their partners from north and west European countries. However, it is clear that many of these countries are still 'playing catch up' as far as welfare provisions are concerned and, while many social workers successfully gained professional qualifications, their employment opportunities are often still very limited and might rely on them getting the funding for and starting up their own agencies - or becoming part of the migrant workforce (Lyons and Hanna 2011)

\section{'Comparing' Social Work Education Programmes}

As is evident from the foregoing, education for the social professions aims to prepare people for variously named occupations in countries which, even within the EU, reflect a wide range of socio-economic conditions and cultural traditions. It was therefore possible to recognise both some common elements and some striking differences in various aspects of professional education. It is also possible to compare systematically some of the organisational aspects of this field.

Firstly, professional education in the EU invariably takes place in the higher education sector (though not necessarily in universities, e.g. Greece and France are notable exceptions). Successful candidates usually gain degrees - or degree equivalent awards - on programmes that last from 3-5 years. Throughout the 1980s and 90s, the UK was unusual (though 
not unique, e.g. France and Austria were other exceptions) in offering professional education over only a 2-year period leading to a non-graduate diploma to more than $50 \%$ of students - as well as having a few paths on 4-year degrees; and a post-graduate route leading (then) to a post-graduate diploma (Lyons La Valle, and Grimwood 1995; Wallis Jones and Lyons 1996). This presented as a very 'confused' picture for many of our European colleagues - though was understandable in terms of the history of British social work education (Lyons 1999ab). Many British academics were advocating for a 3-year degree programme, not least to bring the UK into line with European schools, and were pleased when the Department of Health (though for different reasons) decreed that, from 2004 social work should be based on 3 -year programmes leading to an undergraduate degree (or 2-year programmes leading to masters' degrees). Interestingly, in the post-1990 period, when schools of social work were being established/re-established in countries such as Lithuania and Ukraine, there was an initial emphasis on developing professional education at masters' level. Such programmes tended to recruit people who already had (relevant) degrees and perhaps other professional qualifications and they were clearly aimed at producing staff who, in the absence of home grown social professionals, would become the academic staff or managers of social services in the future - a pattern recognisable in the origins of social work education in the UK.

Perhaps partly related to their length, there is a general view that European programmes have included a stronger theoretical base (than UK professional education) and it was the case that many European degrees in the late twentieth century were more likely to include modules on e.g. history of welfare/social work; demography and epidemiology; and research methods, as well as modules relating to a wider range of social work 'methods', including group work and community work. The first three 'subjects' are rarely taught on UK social work degrees even to this day and much group and community work teaching 'disappeared' when 'community social work' went out of favour and separate community work awards became more widespread and beyond the remit of CCETSW in the 1980s.

However, UK students then and to date have spent proportionally more time in practice placements. Additionally, impressionistic evidence suggests that placements in other countries tends to be in more varied agencies and settings and sometimes more student directed than would be the case in Britain. UK placements, in turn, have had to meet 'stricter' requirements. These include 'supervision' by practice educators who have themselves become increasingly subject to training and qualification requirements. This reflects a 'dichotomy' less evident in other countries apparent in the phrase, 'education and training', and also partly explains why 'ERASMUS placements' seemed less feasible for UK students than for students from many other countries who were often keen to take up placements in the UK. It can also be noted in passing that there has been more emphasis in the UK on developing post-qualifying awards of various kinds, usually in conjunction with employers, relative to little attention to this area in other European countries, some of which however, are more likely to promote higher academic degrees and research. In general, professional education in the UK has been encouraged to have closer relationships with employers (and to respond to the training needs of the social service workforce) and, in the twenty-first century with service users, than has been evident in other European countries.

Returning to the imbalance in the numbers of students pursuing ERASMUS placements, one reason was related to differences in the demographic characteristics between UK students and their counterparts in countries ranging from e.g. Greece to Germany and Sweden. For instance, many students on the Diploma courses were be 'mature students' (defined then as being over 25 years old) and fould have had greater family and financial responsibilities. Another major limitation was 'the language barrier' for British students, some of whom speak another language but not necessarily a European one. Despite English being the lingua franca of much of the working world (and often in the networks and the intensive programmes, European modules and award bearing courses which some organised), European students were in general more likely to speak English than British students (and staff!). Given the importance of verbal and written communication in much social work practice this was indeed a serious deterrent to placements abroad - though there were exceptions (e.g. see case studies in Lyons and Ramanathan 1999).

Notwithstanding the variations in the range and level of 'knowledge' required (and the cultural contexts within which they worked), there were recognisable similarities between the skills expected of European social workers, such as interviewing and assessment, and the client- or user groups to which they would relate and basic values and ehtics were broadly shared. Again,But there were some notable variations, partly related to the organisation of social work. For example, with-some German social workers were involved in administering 'social security'-type benefits, and social workers in Greece and Italy werebeing more closely involved in work in health centres/ polyclinics. Similarly, basic values and ethies, e.g. respect for 'the client' and confidentiality were breadly shared. 
However, there was aAnother noticeable difference in the early days of various European partnerships concerned cultural and ethnic differences. In the 1980s, alongside national policies promoting multiculturalism in the primary and secondary school stage, efforts were also being made to recruit more ethnically diverse student cohorts in higher education. Social work education in particular was increasingly concerned about 'racism' in education and employment opportunities, social services and community relations, and accordingly some coursesschoels were making considerable efforts to develop and implement anti-racist strategies and training programmes (Williams 2016). In my experience, this tended to be seen as a 'British preoccupation' by some European colleagues but there was a recognition, for example in Germany, that attention should be paid to the needs of its own minority ethnic groups (e.g. second-generation Turkish children and youth) leading to the establishment of some specialist services and the development of opportunities for 'intercultural learning' in professional education (Allufi-Pentini and Lorenz 1996). Some networks then or later organised seminars and training programmes for their own staff membership and when British programmes shifted to a wider diversity and equal opportunities agenda there seemed to be greater alignment between professional education across Europe and also with the policies of the EU. Overall, some European schools seem to have shown more enthusiasm for 'international social work', for example, as reflected in teaching about international conventions such as those concerning human rights or the rights of particular groups than British counterparts. However, with the 'turn to the right' in the politics of many European countries, it is likely that social work and professional education will have a harder task promoting the international values (of human rights and social justice) professed in a joint declaration of the Global definition of social work by the IASSW and IFSW in 2014 (http:// www.ifsw.org/policies/definition-of-social-work/).

\section{Concluding Comments}

The early (English language) literature about the history of social work and professional education has tended to focus on national developments, including in the USA and also countries like Australia and Canada - the destination countries for generations of migrants from the British Isles and other European countries. However, the last three decades have seen a significant shift in focus with the establishment of partnerships between UK 'social work schools' (broadly defined) - and also other organisations and groups involved in- or relevant to - social professional work in Europe.

The EU has played a major role in this through funding programmes designed to encourage network formation and activities which further its aspirations for 'a united Europe'. However, the processes of 'Europeanisation' in all fields have not always worked smoothly, nor been universally supported. This has been true in the case of the social professions when, notwithstanding the (continuing) efforts and enthusiasm of the minority of people involved, social work and its related occupations have remained a stubbornly local activity with many professionals failing to acknowledge the relevance of globalisation and regional developments. Similarly, professional education has continued to be shaped by national higher education policies and cultures - and sometimes also by state or professional regulatory requirements with the two sometimes in tension (as in the UK).

Turning to workforce matters, it can be speculated that some of the 'international social workers' currently employed in the UK are people who themselves had the benefit of some learning influenced by 'European experience'. In the context of a general tightening of border controls, one consequence of Britain's membership of the EU has been a shift in recruitment patterns this century away from English-speaking countries (such as Canada and India) to European countries (Lyons and Hanna 2011). The foregoing sections have given an indication of the wide variation in socioeconomic and cultural backgrounds of such recruits and the educational routes which have led them to professional qualification. Assessment of such qualifications as being 'equivalent' to the national award has long been the responsibility of a succession of bodies regulating social work in the UK.

However, once employed, the training needs which such social workers might have in order for them to transfer knowledge and skills effectively have AQ1been a cause for concern (Lyons and Littlechild 2006). It is possible that the different national traditions from which many European recruits have come, together with language issues, mean that they have even greater learning needs than previous cohorts of international social workers. But employment in the UK affords an opportunity for people from countries where there is an oversupply of social professionals (such as Germany, Greece, Spain and Romania) to both extend their own professional learning and to make a contribution to British social services. (The reasons for oversupply in different countries vary but include the non-regulation of the number of places on programmes (unlike the UK) as well as the lack of funding to develop needed services in their own countries.) The extent to which international (including European) social workers can enrich the knowledge base and capacity of the British professional workforce should not be underestimated and in many cases need to be better supported. 
Finally, I conclude that, where staff and students have engaged with opportunities for placements, study and/or research abroad, this has invariably been an enriching experience causing one to think critically about one's own systems, policies and practices, as much as to learn about other ways of thinking and doing things. Additionally, it seems likely that, even if the UK 'leaves Europe' (specifically the EU) - under whatever conditions, there will be an ongoing need for British social workers to be better educated as regards global and regional issues and resources, given the ongoing processes of migration; the increasing diversity of the national population; and the interconnectedness of individuals and societies in a host of ways and at various levels. In its recent history, European funding provided an important opportunity for transnational learning and professional education continues to play a role in 'broadening people's horizons', enabling participantsthem-to see the relevance of events, policies and practices beyond national borders, both in Europe and globally.

\section{Disclosure statement}

No funding was received in relation to production of this article and no conflict of interest needs to be declared.

Practice Article: missing or incomplete refs

Cannan, C. Lyons, Berry, L. and Lyons, K. (1992) Social Work and Europe, Basingstoke, MacMillan

Ginsburg, N. and Lawrence, S. (2006) 'A Changing Europe' in Lyons, K. and Lawence, S. (eds) Social Work in Europe: educating for change, Birmingham, Venture Press

Hatton, K. (2013) Social Pedagogy in the UK: theory and practice, Lyme Regis, Russell House Publishing

Hering S.and Waaldijk, B. (eds) (2003) History of Social Work in Europe, 1900-1960, Opladen, Leske and Budrich

Lyons, K. and Littlechild, B. (eds) (2006) International Labour Mobility in Social Work, Birmingham, Venture Press

Mishra, R. (1999) Globalization and the Welfare State, Cheltenham, Edward Elgar

Walton, R. (1975) Women in Social Work, London, Routledge

\section{References}

Abrahamson, P. 1993. "Welfare Pluralism: Towards a New Consensus for a European Social Policy." Cross-National Research Papers 2 (6): 5-22.

Allufi-Pentini, A., and W. Lorenz . Eds. 1996. Anti-Racist Work with Young People. Lyme Regis: Russell House.

Boddy, J., C. Cameron, and P. Petrie . 2006. "The Professional Care Worker: The Social Pedagogue in Northern Europe." In Care Work: Present and Future, edited by Boddy, J., C. Cameron, and P. Moss . London: Routledge.

Cannan, C., R. Coleman, and K. Lyons . 1990. Europe 2: Links and Exchanges. London: CCETSW.

Chytil, O., and F. Seibel . Eds. 1999. European Dimensions in Training and Practice of Social Professions. Blansko: Albert.

Cooper, A., R. Hetherington, K. Baistow , J. Pitts , and A. Spriggs . 1995. Positive Child Protection. Lyme Regis: Russell House Publishing.

Erath, P., and B. Littlechild . eds. 2010. Social Work across Europe: Accounts from 16 Countries. Ostrava: Albert. Esping-Anderson, G. 1990. The Three Worlds of Welfare Capitalism. Oxford: Policy Press.

Ford, P., and P. Hayes . eds. 1996. Educating for Social Work: Arguments for Optimism. Aldershot: Avebury.

Freitas, M. J., G. Friesenhahn, E. Frost , and M. Michailidis . eds. 2005. Children, Young People and Families: Examining Social Work Practices in Europe. Rome: Carocci.

Ginsburg, N., and S. Lawrence . 2006. “A Changing Europe.” Edited by K. Lyons and S. Lawrence . op.cit.AQ5 
Healy, L. 2001. International Social Work: Professional Action in an Interdependent World. New York: Oxford University Press.

Healy, L. 2012. "The History of the Development of Social Work.” In Handbook of International Social Work: Human Rights, Development and the Global Profession, edited by L. Healy and R. Link . Oxford: Oxford University Press.

Hetherington, R., A. Cooper, P. Smith, and G. Wilford . 1997. Protecting Children: Messages from Europe. Lyme Regis: Russell House Publishing.

Hokenstad, T. 2012. "Social Work Education: The International Dimension." In The SAGE Handbook of International Social Work, edited by K. Lyons, T. Hokenstad, M. Pawar, N. Huegler, and N. Hall . London: Sage.

Kantowicz, E. Ed. 2009. Role of Research in Education for Social Work in Europe. Olsztyn: UWN.

Kendall, K. 2000. Social Work Education: Its Origins in Europe. Alexandria, VA: CSWE.

Laot, F. 2001. Doctoral Studies in Social Work: European Initiatives. Paris: ENSP.

Leskosec, V., and A-L. Matthies . 2017. "Internationalisation of Social Work Doctoral Studies: Experiences and Perspectives in the Changing Context of European Higher Education.” European Journal of Social Work 20 (4): 596-607.

Littlechild, B., P. Erath, and J. Keller . Eds. 2005. De- and Reconstruction in European Social Work. Stassfurt: Albert.

Lorenz, W. 1994. Social Work in a Changing Europe. London: Routledge.

Lyons, K. 1999a. International Social Work: Themes and Perspectives. Aldershot: Ashgate.

Lyons, K. 1999b. Social Work in Higher Education: Demise or Development? Aldershot: Ashgate.

Lyons, K., and S. Hanna . 2011. "European Social Workers in England: Exploring International Labour Mobility." Revista de Asistenta Sociala X: 185-196.

Lyons, K., and N. Huegler . 2012. "European Perspectives on Education for Social Work and Social Pedagogy." In Social Work Education and Training, edited by J. Lishman, Research Highlights 54. London: Jessica Kingsley.

Lyons, K., and S. Lawrence . 2006. Social Work in Europe: Educating for Change. Birmingham: BASW/Venture Press.

Lyons, K., and C. Ramanathan . 1999. "Models of Field Practice in Global Settings." In All Our Futures: Social Work Practice in a Global Era, edited by C. Ramanathan and R. Link . Belmont, CA: Brooks/Cole, Wadsworth.

Lyons, K., I. La Valle , and C. Grimwood . 1995. "Career Patterns of Qualified Social Workers: Discussion of a Recent Survey." BJSW 25 (2): 173-190.

Otto, H-U., and W. Lorenz . 1998. “Editorial.” European Journal of Social Work 1 (1): 1-4.

Petrie P., J. Boddy , C. Cameron , E. Heptinstall , A. McQuail , S. Wigfall , and V. Wigfall . 2009. "Pedagogy - A Holistic, Personal Approach to Work with Children and Young People across Services. European Models for Practice, Training, Education and Qualification.” Briefing Paper from Thomas Coram Research Unit, Institute of Education, University of London. e-prints.ioe.ac.uk/58/1/may_18_09_ped_BRIEFING_PAPER_JB_PP-.pdf.

Rodriguez-Pose, A. 2002. The European Union: Economy, Society and Polity. Oxford: Oxford University Press.

Semigina, T., N. Kabachenko, and O. Boyco . 2017. "Piloting a Social Work Doctoral Programme: Ukraine's Vignette." European Journal of Social Work 20 (2): 265-276.

Wallis Jones, M., and K. Lyons . 1996. Employment Survey of Qualified Social Workers. London: CCETSW.

Williams, C. 2016. "Social Work Education and the Challenge of Race Equality." In Routledge International Handbook of Social Work Education, edited by I. Taylor, M. Bogo , M. Lefevre , and B. Teater. Abingdon: Routledge. https:// www.coe.int/web/aboutus https://europa.eu/european-union/index.

Karen Hamilton Lyons (PhD, CQSW), Emeritus Professor (London Metropolitan University, UK), was previously a social work educator at University of East London. She was a member of a European network for 30 years and represented the UK on the IASSW Board (2000-2004) as well as editing International Social Work (2004-2010). She has contributed to social work programmes in a number of countries beyond Europe and more recently been involved in research about international labour mobility. 
1. The European Centre for Community Education (ECCE) was initiated in 1985 as a network of individuals from a range of departments in universities across the members of the then European Community. Under the leadership of Professor Friedrich Seibel and with the benefit of a succession of ERASM USgrantsto different schools an office was set up in Koblenz (Fachhochschule) and 'membership' was expanded. Apart from the range of activities noted in the foregoing text and the development of teaching materials, in 1995 it won a competitive grant to map and evaluate the impact of ERASM US projects at the point when a new system of funding (SOCRATES) was due to be introduced. SOCRATES shifted funding to 'thematic networks' and ECCE collaborated with other pan-European organisations to establish one for the social professions. The ECCE office closed in 2016 and the network formally disbanded.

2. European Journal of Social Work (EJSW) was not the first European journal. A group of social work educators at Brunel University co-operated with a small publisher (Russell House) to produce a quarterly journal, Social Work in Europe, from 1994. The last issue appeared in 1999 and the journal was incorporated into EJSW from 2000.

3. A notable exception was research carried out by Brunel social work educators and French partners (part-funded by national as well as European money) resulting in two important books in the field of comparative child protection (Cooper et al. 1995; Hetherington et al. 1997). 


\section{Author Queries}

Query: AQ1: Please review the table of contributors below and confirm that the first and last names are structured correctly and that the authors are listed in the correct order of contribution. This check is to ensure that your names will appear correctly online and when the article is indexed.

\section{Sequence Prefix Given name(s) Surname Suffix}

1 Karen Hamilton Lyons

Response: sorry, above should read my name details are correct. Prefix could be Dr. if needed

Query: AQ2: Please provide complete details for (Walton 1975, Hering and Walldjik 2003, Hatton 2013, Cannan et al. 1992, M ishra 1999, and Lyons and Littlechild 2006) in the reference list or delete the citation from the text.

Response: See answer to q 1. A list of missing ref's has been added just before the main ref's section.

Query: AQ3: Please provide the significance for " $(1)$ " in the sentence that begins with "The growing body of literature..." Response: this related to something I thought might be an end note - but it's now a footnote on another page so just omit the 1 from here.

Query: AQ4: Please check the sentence that begins with "In Germany, a high proportion of social professionals..." for clarity.

Response: I have deleted some words and hope this sentence is now understandable.

Query: AQ5: Please provide complete details for reference "Ginsburg and Lawrence (2006)".

Response: this has been included in the added list of missing refs 